\title{
Impact of metabolic control in progression of clinical diabetic nephropathy
}

\author{
G. Nyberg ${ }^{1}$, G. Blohmé ${ }^{2}$ and G. Nordén ${ }^{1}$ \\ Departments of ${ }^{1}$ Nephrology and ${ }^{2}$ Medicine II, Sahlgrenska sjukhuset, University of Göteborg, Göteborg, Sweden
}

\begin{abstract}
Summary. Renal clearance of ${ }^{51} \mathrm{Cr}-\mathrm{EDTA}$ as a measure of glomerular filtration rate was followed prospectively for 21 months in 18 Type 1 (insulin-dependent) patients with juvenile-onset diabetes and nephropathy. Hypertension was treated aggressively, attaining a mean blood pressure of $154 / 88 \mathrm{mmHg}$ in the supine and $126 / 82 \mathrm{mmHg}$ in the standing position. The mean glycosylated haemoglobin value $\left(\mathrm{HbA}_{1 \mathrm{c}}\right)$ during the observation period was found to correlate well with the mean of random blood glucose values $(r=0.72)$.

on the first and last observations only $(r=-0.57, p<0.05)$. In a multiple linear stepwise regression analysis also including mean arterial blood pressure, the correlation between glomerular filtration rate decline and $\mathrm{HbA}_{1 c}$ was significant at $p<$ 0.01 ; this explained one-third of the progression, while mean arterial pressure could not be shown to contribute. It is concluded that hyperglycaemia, contrary to the general belief, is a risk factor for the progression of clinical diabetic nephropathy with reduced glomerular filtration rate.
\end{abstract} It also correlated to the rate of glomerular filtration rate decline over time, whether the latter was calculated as slope coefficient for all available data $(r=-0.52, p<0.05)$ or based

Key words: Glycosylated haemoglobin, diabetic nephropathy, glomerular filtration rate.
It is generally agreed that diabetic nephropathy is the result of hyperglycaemia, whether alone or in combination with some other factor(s) [1-5]. However, once nephropathy is clinically overt, as determined by persistent proteinuria and declining glomerular filtration rate (GFR), the degree of metabolic control is believed to have lost its significance as a risk factor, with other mechanisms having taken over [3-8]. Establishing this as a fact requires a study with a sufficient number of patients, accurate measurements of GFR and adequate control of hypertension, which is the dominant risk factor in this phase of the disease. A study by Viberti et al. [6] showed a GFR fall rate of $8.3 \mathrm{ml} / \mathrm{min}$ per year in six patients during treatment with the subcutaneous pump versus 16.2 during the run-in period. Although the difference was not statistically significant, the result offers little support for the view that metabolic control does not influence GFR decline.

In a previous report [9] on 21 Type 1 diabetic patients with diabetic nephropathy, we found significantly more high $\mathrm{HbA}_{1}$ values in a group of patients with rapid decline of GFR than in groups with slow or no progression. However, in that study some patients still had insufficiently controlled hypertension, and the methods used to measure GFR and glycosylated haemoglobin were not optimal.
The present report is based on results from a new prospective study in 18 of these patients in order to assess metabolic control as a risk factor for the rate of progression.

\section{Subjects and methods}

Eighteen patients with Type 1 diabetes were studied. They had been followed at our clinic since 1980-1981, when they participated in a prospective study lasting one year on the possible effect of a platelet aggregation inhibitor on the rate of decline of GFR [10]. No patients who once entered that study were excluded other than those who had died of cardiac disease $(n=3)$ and those who had undergone renal transplantation $(n=4)$. Four of these events occurred before the previous evaluation [9]. Clinical data, including results of renal biopsy, are presented in Table 1 . The age range for the 18 patients was 23 to 50 years, and the duration of diabetes ranged from 18 to 37 years. All patients had proteinuria, hypertension, proliferative retinopathy and a reduced GFR. Renal biopsy had been attempted in all but one and was successful in 14 , showing only changes compatible with diabetic nephropathy.

Hypertension was treated according to a previously described programme [9] aiming at supine blood pressures not higher than $140 / 90 \mathrm{mmHg}$. Furosemide was used as the first drug, a cardioselective beta-blocking agent as the second, hydralazine as the third and a combination of furosemide and captopril in the fourth step. Finally, a beta-blocking agent and a calcium antagonist were added if necessary. It was possible to control hypertension, as measured in the supine position, in all patients except four who had an unacceptable 
Table 1. Clinical data on 18 Type 1 diabetic patients with diabetic nephropathy

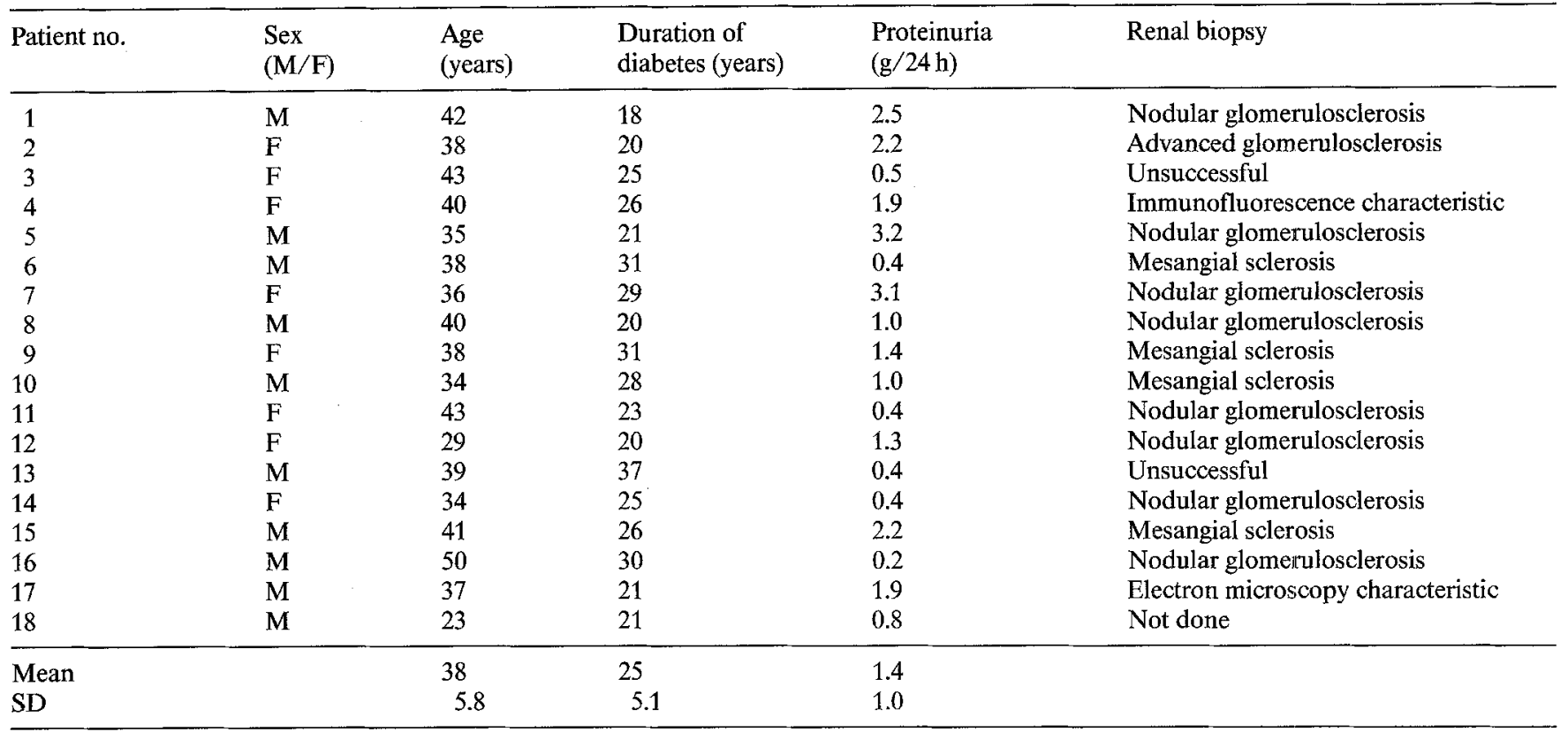

Table 2. Glomerular filtration rate (GFR) measured as renal clearance of ${ }^{51} \mathrm{Cr}$-EDTA in 18 Type 1 diabetic patients with diabetic nephropathy. Delta value calculated on the basis of entry and exit values only

\begin{tabular}{llllll}
\hline $\begin{array}{l}\text { Patient } \\
\text { no. }\end{array}$ & $\begin{array}{l}\text { GFR at entry } \\
(\mathrm{ml} / \mathrm{min})\end{array}$ & $\begin{array}{l}\text { GFR at exit } \\
(\mathrm{ml} / \mathrm{min})\end{array}$ & $\begin{array}{l}\text { Observation } \\
\text { time (months) }\end{array}$ & $\begin{array}{l}\text { Delta value } \\
\text { (ml/min per year) }\end{array}$ & $\begin{array}{l}\text { Linear slope } \\
\text { coefficient } \\
\text { (ml/min per year) }\end{array}$ \\
\hline 1 & 23 & 28 & 19 & +3.2 & +2.3 \\
2 & 17 & 9 & 24 & -4.0 & -2.6 \\
observations
\end{tabular}

blood pressure fall in the standing position. This degree of blood pressure control was already achieved when the present study started, but adjustments to the treatment were made during the study when unacceptable pressures were recorded.

The follow-up time was 21 months (range 17-25). During this time, GFR was measured 4-7 times per patient using the renal clearance of ${ }^{51} \mathrm{Cr}$-EDTA given in a single bolus injection [11]. In contrast to the plasma clearance technique used in the previous study [9], this method allows estimation of GFR at levels below $20 \mathrm{ml} / \mathrm{min}$. Each measurement was based on four periods of $40 \mathrm{~min}$. Urine was collected after spontaneous voiding.

All patients were instructed to perform self-monitoring of blood glucose, to take multiple insulin injections and to vary the dosage according to the results of the tests and variations in daily activities. The patients' readiness or ability to follow these instructions varied widely.
During the follow-up time, $\mathrm{HbA}_{\mathrm{tc}}$ was determined by an HPLAtechnique (normal range 3.4-5.4\%) 6-14 times per patient (average 10). Blood glucose was generally measured with strips and sometimes with a reflectometer, but on random occasions tests with the glucoseoxidase technique were made (median 10.5 times per patient). The means of the latter values were compared with the $\mathrm{HbA}_{1 \mathrm{c}}$ values.

\section{Statistical analysis}

The statistical methods used to analyse data were linear regression analysis and forward stepwise multiple linear regression using a Hewlett Packard computer standard pack. A $p$ value of $<0.05$ was considered statistically significant. 
Table 3. Metabolic control in 18 Type 1 diabetic patients with diabetic nephropathy

\begin{tabular}{llcll}
\hline $\begin{array}{l}\text { Patient } \\
\text { no. }\end{array}$ & $\begin{array}{l}\text { Mean } \\
\mathrm{HbA}_{1 \mathrm{c}} \\
(\%)\end{array}$ & $\begin{array}{l}\text { Number of } \\
\mathrm{HbA}_{1 \mathrm{c}} \\
\text { observations }\end{array}$ & $\begin{array}{l}\text { Mean of } \\
\text { random blood } \\
\text { glucose values } \\
(\mathrm{mmol} / \mathrm{l})\end{array}$ & $\begin{array}{l}\text { Number of } \\
\text { daily insulin } \\
\text { injection doses }\end{array}$ \\
\hline 1 & 10.4 & 9 & 10.6 & 4 \\
2 & 10.2 & 14 & 11.0 & 2 \\
3 & 8.2 & 8 & 7.7 & 2 \\
4 & 11.0 & 11 & 14.3 & 4 \\
5 & 9.2 & 8 & 8.9 & 3 \\
6 & 7.7 & 7 & 4.8 & 2 \\
7 & 12.4 & 12 & 22.4 & 2 \\
8 & 11.6 & 10 & 14.4 & 2 \\
9 & 10.2 & 8 & 16.2 & 3 \\
10 & 11.4 & 9 & 9.1 & 3 \\
11 & 10.1 & 6 & 17.5 & 2 \\
12 & 12.0 & 11 & 15.6 & 2 \\
13 & 8.1 & 10 & 12.6 & 2 \\
14 & 8.8 & 9 & 10.7 & 2 \\
15 & 8.6 & 10 & 11.3 & 2 \\
16 & 9.2 & 8 & 10.5 & 2 \\
17 & 8.7 & 10 & 7.2 & 2 \\
18 & 8.5 & 11 & 7.1 & 2 \\
\hline Mean & 9.8 & 9.5 & 11.8 & 2.4 \\
SD & 1.4 & 1.9 & 4.4 & 0.7 \\
\hline & & & &
\end{tabular}

Table 4. Blood pressure control in 18 Type 1 diabetic patients with diabetic nephropathy

\begin{tabular}{llrlll}
\hline $\begin{array}{l}\text { Patient } \\
\text { no. }\end{array}$ & \begin{tabular}{c} 
Supine \\
\cline { 2 - 5 } $\begin{array}{c}\text { Syst/diast } \\
\text { (mmHg) }\end{array}$
\end{tabular} & $\begin{array}{c}\text { Standing } \\
\text { Syst/diast } \\
\text { (mmHg) }\end{array}$ & $\begin{array}{l}\text { Number of } \\
\text { observations } \\
\text { supine/ } \\
\text { standing }\end{array}$ & Medication \\
\hline 1 & $156 / 85$ & 109 & $111 / 76$ & $9 / 8$ & F B H \\
2 & $174 / 99$ & 124 & $136 / 89$ & $12 / 12$ & F B \\
3 & $156 / 83$ & 107 & $130 / 73$ & $8 / 7$ & F \\
4 & $155 / 84$ & 108 & $128 / 80$ & $11 / 11$ & F B H \\
5 & $154 / 84$ & 107 & $136 / 84$ & $7 / 7$ & F B H \\
6 & $140 / 90$ & 107 & $114 / 91$ & $7 / 6$ & F B H \\
7 & $167 / 91$ & 116 & $109 / 77$ & $12 / 11$ & F ACE H \\
8 & $145 / 93$ & 110 & $124 / 88$ & $12 / 10$ & F B ACE \\
9 & $144 / 83$ & 103 & $111 / 71$ & $7 / 6$ & F B \\
10 & $136 / 86$ & 105 & $126 / 86$ & $9 / 9$ & F ACE \\
11 & $154 / 87$ & 109 & $115 / 76$ & $6 / 6$ & F B \\
12 & $181 / 95$ & 124 & $157 / 91$ & $14 / 13$ & F B ACE \\
13 & $130 / 84$ & 99 & $129 / 91$ & $11 / 8$ & F B \\
14 & $150 / 80$ & 103 & $130 / 74$ & $12 / 11$ & F B H \\
15 & $163 / 89$ & 114 & $128 / 81$ & $10 / 10$ & F (+ B) \\
16 & $173 / 102$ & 126 & $129 / 83$ & $14 / 12$ & F ACE \\
17 & $153 / 83$ & 106 & $138 / 82$ & $11 / 11$ & F B Ca \\
18 & $134 / 89$ & 104 & $135 / 92$ & $13 / 11$ & F ACE \\
\hline Mean & $154 / 88$ & 110 & $126 / 82$ & $10.3 / 9.4$ & \\
SD & $14 / 6$ & 7.8 & $12 / 7$ & $2.5 / 2.3$ & \\
\hline
\end{tabular}

a $\mathrm{F}=$ furosemide, $\mathrm{B}=$ cardioselective beta blocking agent, $\mathrm{H}=$ hydralazine, $\mathrm{ACE}=$ captopril, $\mathrm{Ca}=$ calcium antagonist. Change during study marked ()

\section{Results}

Individual data for GFR are presented in Table 2. The mean GFR \pm SD at entry was $35.3 \pm 11.7 \mathrm{ml} / \mathrm{min}$ per $1.73 \mathrm{~m}^{2}$ (range 16-55) and at follow-up $30.7 \pm 12.3$

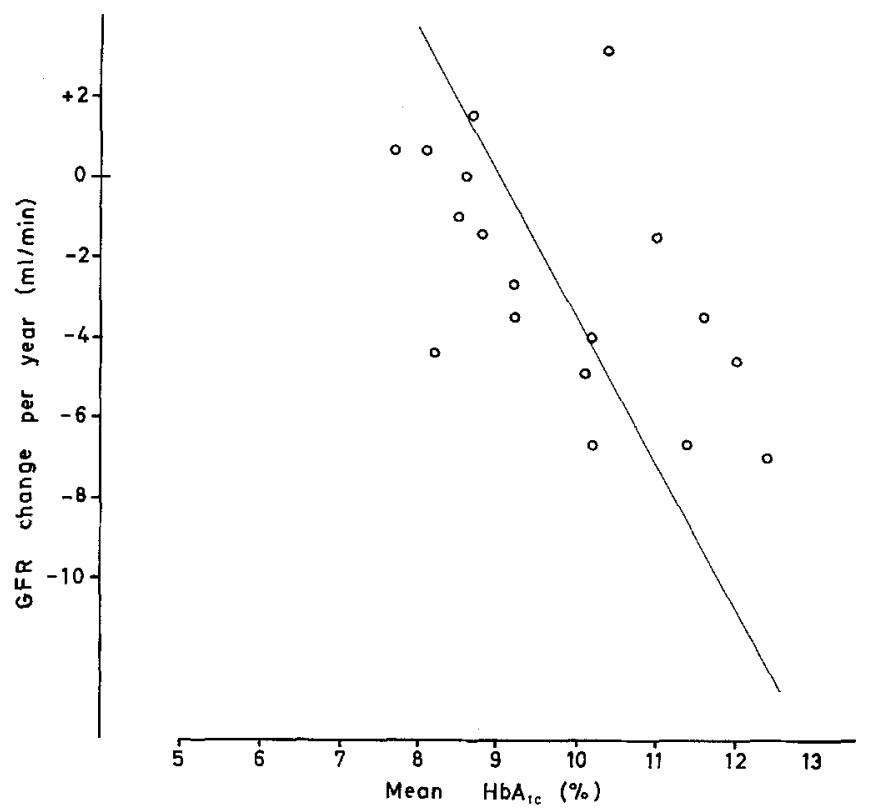

Fig. 1. Correlation between glomerular filtration rate (GFR) change over time (based on first and last observations) and mean $\mathrm{HbA}_{1 \mathrm{c}}$ in 18 Type 1 patients with diabetic nephropathy $(r=-0.57, p<0.05)$

(range 9-52). The mean GFR change as based on these data ("delta" value) was $-2.5 \mathrm{ml} / \mathrm{min}$ per year and ranged from -7.0 to $+3.2 \mathrm{ml} / \mathrm{min}$, while the individual linear slope coefficients for GFR over time in the 18 patients ranged from -7.2 to $+2.4 \mathrm{ml} / \mathrm{min}$ per year, mean value -2.4 . As progression was slow or none in most cases, the regression coefficients for these individual slopes were often not statistically significant. However, the "slope" and "delta" values were closely correlated $(r=0.90, p<0.001)$.

Table 3 shows data on glucose control. $\mathrm{HbA}_{1 \mathrm{c}}$ values ranged from 7.7 to $12.4 \%$. There was a highly significant correlation between mean $\mathrm{HbA}_{1 \mathrm{c}}$ values for each patient and mean blood glucose values recorded during the observation period ( $r=0.72, p<0.001)$. GFR at exit and the $\mathrm{HbA}_{1 \mathrm{c}}$ value at exit were not significantly correlated in the 18 individual patients $(r=-0.16)$.

Mean blood pressure during the study was $154 \pm$ $14 / 88 \pm 6 \mathrm{mmHg}$ in the supine position and $126 \pm$ $12 / 82 \pm 7 \mathrm{mmHg}$ standing (Table 4 ). The mean arterial pressure (MAP) in the supine position ranged from 99 to 126.

In the linear regression analysis, GFR change over time was significantly correlated to the patient's mean $\mathrm{HbA}_{1 \mathrm{c}}$ value (Figure 1) (for delta $r=-0.57$, for slope $r=-0.52, p<0.05$ ) but not to mean supine MAP (for delta $r=-0.28$, for slope $r=-0.22, p>0.05$ ). Multiple linear regression analysis of the GFR over time as the dependent variable and mean $\mathrm{HbA}_{1 \mathrm{c}}$ and mean MAP, as the independent variables still showed a significant correlation for $\mathrm{HbA}_{1 \mathrm{c}}(p<0.01)$, which predicted $32 \%$ of progression based on delta values and $27 \%$ of slope values. MAP, on the other hand, could not be shown to predict progression significantly. 


\section{Discussion}

The term "self-perpetuating" that is often applied to the course of renal function in patients like those now studied emanates from the time when nothing was known about the factors ruling the progression. Hypertension has now been recognised as the dominant risk factor $[12,13]$, and with antihypertensive treatment the progression can be reduced to a small proportion of that in the uncontrolled state. However, progression to uraemia is still considered to be inevitable $[3,5,6]$, and the responsible factors are not identified.

For studies on the progression of renal insufficiency, reliable methods must be used to measure renal function. Substitutes for GFR measurements, such as serum creatinine, are not good enough for scientific purposes and cannot alone be trusted for clinical use [14-15]. The renal clearance of ${ }^{51} \mathrm{Cr}$-EDTA, which we used, truly reflects GFR and is reliable at rates as low as $2-3 \mathrm{ml} / \mathrm{min}$ [11]. As for all renal clearance techniques, it has the drawback of possible urine sampling errors unless an indwelling catheter is used. The effects of any sampling errors are, however, reduced by use of multiple collection periods. To reduce methodological errors, we also used a slope coefficient based on all available GFR values in addition to the first and last determinations; these obtained mainly the same results.

The patients studied were especially suited, because a good blood pressure control had been established and was maintained during the study. In the multiple regression analysis MAP did not show to be a risk factor for progression. Nevertheless, blood pressure may have been of importance because the highest MAP values were recorded in patients with a pronounced blood pressure fall in the standing position; these subjects may well have had an adequate blood pressure during most time of the day. Therefore, we do not conclude that an optimal blood pressure level was achieved in all patients. However, the degree of control was good enough to obtain an extremely low rate of progression and to demonstrate that metabolic control is another risk factor of importance. From a logical standpoint, this is not unexpected; the mechanisms by which hyperglycaemia causes glomerulopathy should be operating in those glomeruli that are still functioning unless they have developed a remarkable resistance.

The value of $\mathrm{HbA}_{1}$-determination has been disputed in uraemia on the basis of studies with varying results in non-diabetic uraemic patients [16-18], from increases by 3.7 or $1.9 \%$ units to a reduction of about $1.5 \%$ units compared to non-diabetic control subjects with normal renal function. These and similar reports have had a repressive effect on the use of, or at least the publication of, $\mathrm{HbA}_{1}$ values as a measure of metabolic control in patients with diabetic nephropathy. However, a strikingly concomitant decline of blood glucose and $\mathrm{HbA}_{1}$ has been reported in several intervention studies $[6,19$, $20]$. In the present investigation we measured the more specific $\mathrm{HbA}_{1 \mathrm{c}}$ fraction [16] which has been found to correlate closely $(r=0.92)$ to blood glucose profiles recorded in subjects with diabetic nephropathy [21]. The strong correlation between $\mathrm{HbA}_{1 \mathrm{c}}$ and mean of random blood glucose values and the lack of correlation between individual $\mathrm{HbA}_{1 \mathrm{c}}$ and GFR values further indicate that $\mathrm{HbA}_{\mathrm{ic}}$ is a valid measure of metabolic control in patients with diabetic nephropathy, at least as long as they are not terminally uraemic.

The degree of metabolic control in our patients varied widely. This was not the result of varying ambition on our side, but on the patients' compliance. Three of four patients with $\mathrm{HbA}_{1 \mathrm{c}}$ values exceeding $11 \%$ frankly declared that they did not find it compatible with a decent life to perform self-monitoring of blood glucose or to take insulin more than twice daily. They were also non-compliant with regard to their diet. This was in sharp contrast to their willingness to accept antihypertensive therapy, which was not considered to interfere with their quality of life.

We think that recognition of metabolic control as a second risk factor in clinical diabetic nephropathy is important because progression can probably be further delayed by better metabolic control. Furthermore, the notion that metabolic control does not matter any longer in these patients tends to worsen their overall care by offering an excuse to physicians and patients who do not want to make the effort. Since kidney transplantation is now available for diabetic patients, the chances are good that these patients will live for several, if not many, more years. Good metabolic control may contribute to the retardation of further development of diabetic complications, including recurrence of diabetic nephropathy in the transplanted kidney.

\section{References}

1. Mauer SM, Steffes MW, Brown DM (1981) The kidney in diabetes. Am J Med 70: 603-612

2. Mogensen CE, Christensen CK, Vittinghus E (1983) The stages in diabetic renal disease. With emphasis on the stage of incipient diabetic nephropathy. Diabetes 32 [Suppl 2]: 64-78

3. Hostetter TH (1985) Diabetic nephropathy. N Engl J Med 312: 642-643

4. Hasslacher Ch, Stech W, Wahl P, Ritz E (1985) Blood pressure and metabolic control as risk factors for nephropathy in type 1 (insulin-dependent) diabetes. Diabetologia 28:6-11

5. Krolewski AS, Warram JH, Christlieb AR, Busick EJ, Kahn CR (1985) The changing natural history of nephropathy in type I diabetes. Am J Med 78: 785-794

6. Viberti GC, Bilous RW, Mackintosh D, Bending JJ, Keen $\mathbf{H}$ (1983) Long term correction of hyperglycaemia and progression of renal failure in insulin dependent diabetes. $\mathrm{Br}$ Med J 286: 598-602

7. Parving H-H, Smidt UM, Friisberg B, Bonnevie-Nielsen V, Andersen AR (1981) A prospective study of glomerular filtration rate and arterial blood pressure in insulin-dependent diabetics with diabetic nephropathy. Diabetologia 20:457-461

8. Mauer SM, Steffes MW, Goetz FC, Sutherland DER, Brown DM (1983) Diabetic nephropathy. A perspective. Diabetes 32 [Suppl 2]: 52-55 
9. Nyberg G, Blohmé G, Nordén G (1986) Constant glomerular filtration rate in diabetic nephropathy - correlation to blood pressure and blood glucose control. Acta Med Scand 219: 67-72

10. Nyberg G, Larsson O, Westberg NG, Aurell M, Jagenburg R, Blohmé $G$ (1984) A platelet aggregation inhibitor - ticlopidine in diabetic nephropathy: a randomized double blind study. Clin Nephrol 21: 184-187

11. Jagenburg R, Attman P-O, Aurell M, Bucht H (1978) Determination of glomerular filtration rate in advanced renal insufficiency. Scand J Urol Nephrol 12: 133-137

12. Mogensen CE (1982) Long-term antihypertensive treatment inhibiting progression of diabetic nephropathy. Br Med J 285: 685-688

13. Parving H-H, Smidt UM, Andersen AR, Svendsen PA (1983) Early aggressive antihypertensive treatment reduces rate of decline in kidney function in diabetic nephropathy. Lancet 1: 1175-1179

14. Shemesh O, Golbetz H, Kriss JP, Myers BD (1985) Limitations of creatinine as a filtration marker in glomerulopathic patients. Kidney Int 28: 830-838

15. Nordén G, Björck S, Granerus G, Nyberg G (1987) Estimation of renal function in diabetic nephropathy - comparison of five methods. Nephron (in press)

16. Fluckiger R, Harmon W, Meier W, Loo S, Gabbay KH (1981) Hemoglobin carbamylation in uremia. N Engl J Med 304: 823-827
17. Freedman D, Dandona P, Fernando O, Moorhead JF (1982) Glycosylated haemoglobin in chronic renal failure and after renal transplantation. J Clin Pathol 35: 737-739

18. de Boer M-J, Miedema K, Casparie AF (1980) Glycosylated haemoglobin in renal failure. Diabetologia 18: 437-440

19. Beyer MM (1984) Diabetic nephropathy. Pediatr Clin North Am 31: 635-651

20. Ciavarella A, Vannini P. Flammini M, Bacci L, Forlani G, Borgnino LC (1985) Effect of long-term near-normoglycemia on the progression of diabetic nephropathy. Diabete Metab 11:3-8

21. Berglund J, Lins L-E, Lins P-E (1985) Metabolic and blood pressure monitoring in diabetic renal failure. Acta Med Scand 218: 401-408

Received: 24 September 1986

and in revised form: 23 December 1986

Dr. G. Nyberg

Department of Nephrology

Sahlgrenska Sjukhuset

University of Göteborg

S-41345 Göteborg

Sweden 